\title{
Analysis of Pond Land Suitability for Catfish Cultivation using GIS in Padang City
}

\author{
Siti Aisyah, Abdullah Munzir, Muzzneena Ahmad Mustapha, Aprizon Putra
}

\begin{abstract}
The pond land suitability in a fish cultivation business is very necessary to be considered to increase the catfish production in Padang city suitability can be done based on 2 aspects, i.e economic (economic evaluation) and physical evaluation. This research aims to the analysis of pond land suitability for the cultivation of catfish enlargement in Padang city using Geographic Information System (GIS) application. The method is overlaid using 9 parameters: a) cultivation pond; b) distance of cultivation from transportation facilities; $c$ ) location of cultivation from water sources (rivers/drainage); d) slope; e) soil type; f) land use; g) altitude; h) flood disaster; and i) landslide, then obtained the result of the most suitable area for the catfish cultivation in Padang city is Kuranji Sub-district with the most important parameter is the land use.
\end{abstract}

Keywords: pond, suitability, catfish, cultivation, GIS, Padang.

\section{INTRODUCTION}

$T_{\text {he fishery sub-sector has strategic value especially in }}$ fulfilling animal proteins for the public in addition to contributing to the economy in Padang city. The fisheries sub-sector is the first largest contributor to Gross Regional Domestic Product (GRDP). Seen from GRDP Padang city 2011 the business field of fisheries at 7.04 billion, in 2012 for 7.53 billion, and in 2013 for 7.89 billion [1]. This indicates that the fishery subsector has increased annually. Types of fish commonly cultivated by fish farmers in Padang city in the year 2013-2015 among others are goldfish, parrotfish, gourami fish, catfish, and grouper [2]. Based on statistical data of fisheries production of fish cultivation in Padang City [3] shows that in the 3 consecutive years catfish occupy the highest position of all types of fish consumption, Catfish production number every year is always increased by $1,321.12$ tons in the year 2013, as much as 1.521.28 tons in 2014, and as much as 2,106.01 tons in 2015 this is due to market demand for catfish that continues to increase. [4] explain that catfish is one of the important alternative freshwater superior commodities in the context of fulfilling community nutrition improvement. Catfish agribusiness is currently developing rapidly. The main market for catfish is

Revised Manuscript Received on May 15, 2020.

* Correspondence Author

Siti Aisyah*, Study Program, Fishing Business, Polytechnic of Pariaman Marine and Fisheries, Indonesia. Email: s.aisyah2795@gmail.com

Abdullah Munzir, Faculty of Fisheries and Marine Sciences, University of Bung Hatta, Padang, Indonesia. Email: munzir@bunghatta.ac.id

Muzzneena Ahmad Mustapha, Professor of geography and natural resources in Faculty of Science and Technology, Universiti Kebangsaan Malaysia, Kuala Lumpur, Malaysia. Email: muzz@ukm.edu.my

Aprizon Putra, Department of doctoral program of environmental science, Universitas Negeri Padang, Indonesia. Email: aprizonputra@gmail.com

(c) The Authors. Published by Blue Eyes Intelligence Engineering and Sciences Publication (BEIESP). This is an open access article under the CC BY-NC-ND license (http://creativecommons.org/licenses/by-nc-nd/4.0/)
Lesehan food stalls and catfish pecel, besides that fresh catfish or various processed catfish are starting to be found in restaurants, supermarkets, and processed industries.

According to [6], the marketing of catfish has grown in many areas of West Sumatra Province including coastal areas. The catfish aquaculture is considered by the coastal community as an alternative option to divert activities from fishing to fish cultivation. Its uncomplicated technology, low investment costs and government support are important reasons for small farmers who running a cultivation business in part or in full. Based on research [6] in Padang City, the average production of catfish each year continues to increase. But the result of the production of catfish in Padang City lower than the production of fish the other regency/city in West Sumatra Province, this is due to the limited production land as the capital of the province with a high level of land-use competition. Data on fish production using pond media in Padang City in 2011 was 89.22 tons, in 2012 were 2762.04, in 2013 were 2187.53 tons, in 2014 were 2141.33 tons, and in 2015 were 2980.74 tons [7]. The production of catfish in Padang City should be bigger, considering the market demand in Padang city is very high, one way to increase catfish production is to analyze the efficiency of fish production of catfish in Padang city. In the implementation of enlargement of fish cultivation activities, every fish farmer always expects success in his efforts by examining the level of profit gained. Therefore, the efficient use of production factors is necessary to produce the maximum output. In addition to seeing the level of efficiency of business cultivation success of cultivation can be seen from the class of pond land suitability, pond land suitability can be done based on 2 aspects, i.e economically (economic evaluation) and physically (physical evaluation) [8]. [9] adds economic suitability is evaluated based on an analysis of costs and benefits of certain forms of land use, while physical suitability is evaluated based on the physical nature of the environment such as climate, soil and topography. Along with current technological developments, it is very necessary to process data faster and can cover a wider area of spatial conditions and attributes in digital form. The technology in question is the technology of GIS. Because according to [10] GIS is a very useful information system to help decision making because it can manage and analyze partial and textual data. Thus, the information generated is not only textual or descriptive but also information about its location. Based on the description above, this study aims to an analysis of pond land suitability for catfish cultivation using GIS in Padang City.

Published By:

Blue Eyes Intelligence Engineering

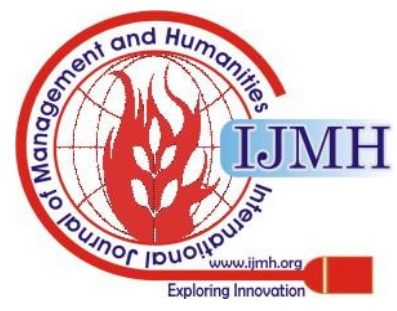




\section{RESEARCH METHODS}

Overall research was conducted during January - April 2018. Based on secondary data [3], there are 30 groups of catfish cultivation in Padang City which spread over 8 sub-districts i.e Bungus Teluk Kabung, Lubuk Begalung (1), South Padang (3), North Padang (2), Nanggalo (1), Kuranji (11), Pauh (2) and Koto Tangah (9) [Fig 1).

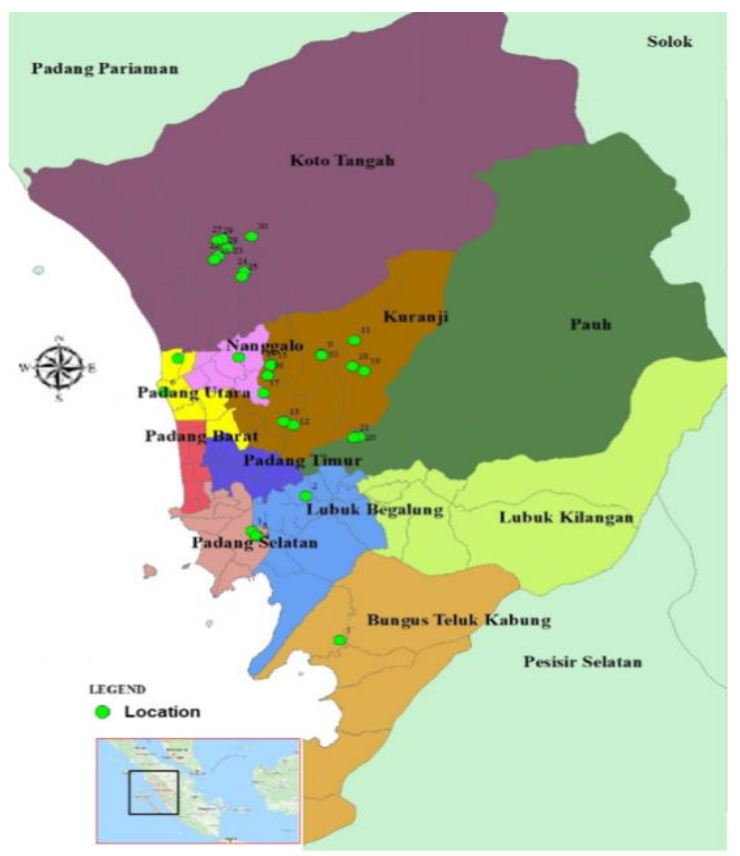

Fig 1. Map of research location points

Where the population in this research are all areas of Padang City. Sampling point determination is performed in Purposive sampling, at each point of the sample carried out measurements, observations, and interviews. Whereas for the GIS software used to analyze the data in the circuit is the Arc Gis 10.3 program conducted in GIS Laboratory of University Kebangsaan Malaysia, Kuala Lumpur.

For analyzing of pond land suitability, the required parameters are the pond land suitability of catfish cultivation, distance from the cultivation location of transportation, distance from the cultivation of rivers, slope, soil type, land use, altitude, flood disaster and landslide. Where the source of the observed parameters for the pond land suitability of catfish cultivation can be seen in Table 1 below.

Tabel-1 Data Sources Parameters Observed

\begin{tabular}{|c|c|c|}
\hline No & Data Source & Parameters \\
\hline \multirow[t]{6}{*}{1} & \multirow{6}{*}{$\begin{array}{l}\text { Direct observation } \\
\text { at the study site } \\
\text { using weighting }\end{array}$} & Criteria 1 \\
\hline & & $\begin{array}{l}\text { Temperature, brightness, colour, smell, } \\
\text { pH, DO, salinity, ammonia, nitrate, an } \\
\text { abundance of plankton }\end{array}$ \\
\hline & & Criteria 2 \\
\hline & & $\begin{array}{l}\text { Pond shape, pool type, water height, water } \\
\text { source, pond shade, hazardous biota, pool } \\
\text { water availability, topographical condition }\end{array}$ \\
\hline & & Criteria 3 \\
\hline & & Ease of access, security, legality aspect \\
\hline \multirow[t]{2}{*}{2} & $\begin{array}{l}\text { Measurement } \\
\text { using the software }\end{array}$ & $\begin{array}{l}\text { The cultivation location distance from the } \\
\text { transportation }\end{array}$ \\
\hline & $\begin{array}{l}\text { help of Arc GIS } \\
\text { and Google Earth }\end{array}$ & Distance from the river cultivation location \\
\hline 3 & $\begin{array}{l}\text { Secondary data } \\
\text { obtained from } \\
\text { relevant agencies }\end{array}$ & $\begin{array}{l}\text { Map of the slope, map of soil type, land use } \\
\text { map, altitude map, disaster-prone map (flood } \\
\text { and landslide) }\end{array}$ \\
\hline
\end{tabular}

Matrix of pond suitability parameters for catfish cultivation is a modification of [8, 11-12] adjusting to the standard [13]. As for how to calculate the pond land suitability for catfish cultivation is referring to the following formula [14]

$$
R C I=\sum\left[N_{i} / N_{m a z}\right] \times 100 \%
$$

Information :

RCI = Regional Criteria Index

$\mathrm{N}_{\mathrm{i}}=$ Value of Parameter to $-\mathrm{i}$

$\mathrm{N}_{\max }=$ Maximum value of a region category

Where the calculation of pond suitability of catfish cultivation uses the parameter matrix in Table-2 below.

Table-2 Matrix of Pond Land Suitability Parameters of Catfish Cultivation

\begin{tabular}{|c|c|c|c|c|c|c|}
\hline \multirow{2}{*}{ Parameters } & \multirow{2}{*}{ Unit } & \multirow{2}{*}{ Weights } & \multicolumn{4}{|c|}{ Category } \\
\hline & & & VS & ES & $\mathrm{CS}$ & NS \\
\hline \multicolumn{7}{|l|}{ Criteria $1(50 \%)$} \\
\hline \multicolumn{7}{|l|}{ Physics: } \\
\hline Brightness & $\mathrm{Cm}$ & 5 & $15-20$ & $21-30$ & $31-35$ & $>36$ \\
\hline Colour & - & 5 & green, greenery & brownish, brownish green & black & dark black \\
\hline Smell & - & 5 & are & smell sharp & sting & very sting \\
\hline \multicolumn{7}{|l|}{ Chemical: } \\
\hline $\mathrm{pH}$ & - & 3 & $7-8$ & 6,9 & $10,5-6$ & $>10<5$ \\
\hline Do & $\mathrm{Mg} / \mathrm{L}$ & 3 & $4-5$ & 3 & 2 & $<1$ \\
\hline Salinity & ppm & 3 & 0 & 1 & 2 & $>2$ \\
\hline Ammonia & ppm & 3 & $0-0,01$ & $0,01-0,08$ & $0,08-0,1$ & $>0,1$ \\
\hline Nitrate & $\mathrm{Mg} / \mathrm{L}$ & 3 & 10 & $11-12$ & $13-14$ & $>14$ \\
\hline \multicolumn{7}{|l|}{ Biology: } \\
\hline $\begin{array}{l}\text { The abundance of } \\
\text { Plankton }\end{array}$ & Ind/L & 5 & $>15.000$ & $10.000-15.000$ & $2000-15000$ & $<2000$ \\
\hline \multicolumn{7}{|l|}{ Criteria 2 (40\%) } \\
\hline Pool type & Unit & 5 & $\begin{array}{l}\text { Semi-Permanent (Muddy } \\
\text { concrete) }\end{array}$ & Concrete, tarp & Rice fields & KJA \\
\hline High Water Pond & $\mathrm{Cm}$ & 5 & $70-100$ & $65-70$ & $30-65$ & $<30$ \\
\hline \multicolumn{4}{|c|}{$\begin{array}{l}\text { Retrieval Number: I0880054920/2020@BEIESP } \\
\text { DOI: } 10.35940 / \text { ijmh.I0880.054920 } \\
\text { Journal Website: } \text { www.ijmh.org }\end{array}$} & \multicolumn{2}{|c|}{$\begin{array}{l}\text { Published By: } \\
\text { Blue Eyes Intelligence Engineering } \\
\text { \& Sciences Publication } \\
\text { (C) Copyright: All rights reserved. }\end{array}$} & \\
\hline
\end{tabular}




\begin{tabular}{|c|c|c|c|c|c|c|}
\hline \multirow{2}{*}{ Parameters } & \multirow{2}{*}{ Unit } & \multirow{2}{*}{ Weights } & \multicolumn{4}{|c|}{ Category } \\
\hline & & & VS & ES & $\mathrm{CS}$ & NS \\
\hline Pond Water Source & - & 3 & Paddy Fields, Plantation & River & Well & Contaminated irrigation tract \\
\hline Pool Shade & - & 5 & Permanent Shade & Shady trees & Outdoor Pool & Always hit by the sun \\
\hline Dangerous biota & - & 3 & No & Snake & Snake, Aligator fish & Snake, alligator fish, crocodile \\
\hline Water availability & - & 3 & $\begin{array}{l}\text { Available throughout the } \\
\text { year }\end{array}$ & Enough & $\begin{array}{l}\text { Limited if the water } \\
\text { dry season (drought) }\end{array}$ & Just rain \\
\hline $\begin{array}{l}\text { Topographical } \\
\text { conditions }\end{array}$ & - & 3 & Good & Are & Ugly, swamp & $\begin{array}{l}\text { Very bad, always exposed to } \\
\text { flooding when it rains }\end{array}$ \\
\hline \multicolumn{7}{|l|}{ Criteria 3 (10\%) } \\
\hline Ironing facilities & - & 3 & Easy & Are & Somewhat difficult & Difficult \\
\hline Security & - & 3 & Safe & Are & Less secure & Unsafe \\
\hline Legal aspects & - & 3 & $\begin{array}{l}\text { According to local } \\
\text { regulation }\end{array}$ & $\begin{array}{l}\text { Not yet compliant with } \\
\text { local regulation }\end{array}$ & $\begin{array}{l}\text { Unplanned local } \\
\text { regulation }\end{array}$ & $\begin{array}{l}\text { Not compliant with local } \\
\text { regulation }\end{array}$ \\
\hline
\end{tabular}

Source: Modifications [8, 11-12] refer to [13].

Information :

VS: Very Suitable with a score of $80-100 \%$

ES: Enough Suitable with a score of $55-<80$

CS: Conditional Suitable with a score of $20-<55$.

NS: Not Suitable with a value $<20$

The method of analysis overlays on the whole map of parameters already in the form of the raster will result in one map of pond land suitability for the enlargement of catfish cultivation in Padang city and do test $\mathrm{T}$ to see the influence of Each parameter statistically against the pond land suitability of catfish cultivation in Padang city.

\section{RESULT}

This analysis of pond suitability using 9 parameters (Table 1), the first parameter is the pond suitability of catfish cultivation, the measurement results showed not too many variations of results, which range from $87.35 \%$ to $97.86 \%$. The highest pond suitability is in Lubuk Begalung sub-district of $97.86 \%$. Pond land suitability for the cultivation of catfish enlargement in Padang City can be seen in Table 3 and Fig 2 below.

Table-3 Pond Suitability for Catfish Cultivation

\begin{tabular}{lc}
\hline \multicolumn{1}{c}{ District } & Suitability \\
\hline Lubuk Begalung & $97,86 \%$ \\
Kuranji & $96,26 \%$ \\
Koto Tangah & $95,11 \%$ \\
North Padang & $94,64 \%$ \\
South Padang & $92,48 \%$ \\
Bungus Teluk Kabung & $91,35 \%$ \\
Pauh & $89,89 \%$ \\
Nanggalo & $87,35 \%$ \\
\hline
\end{tabular}

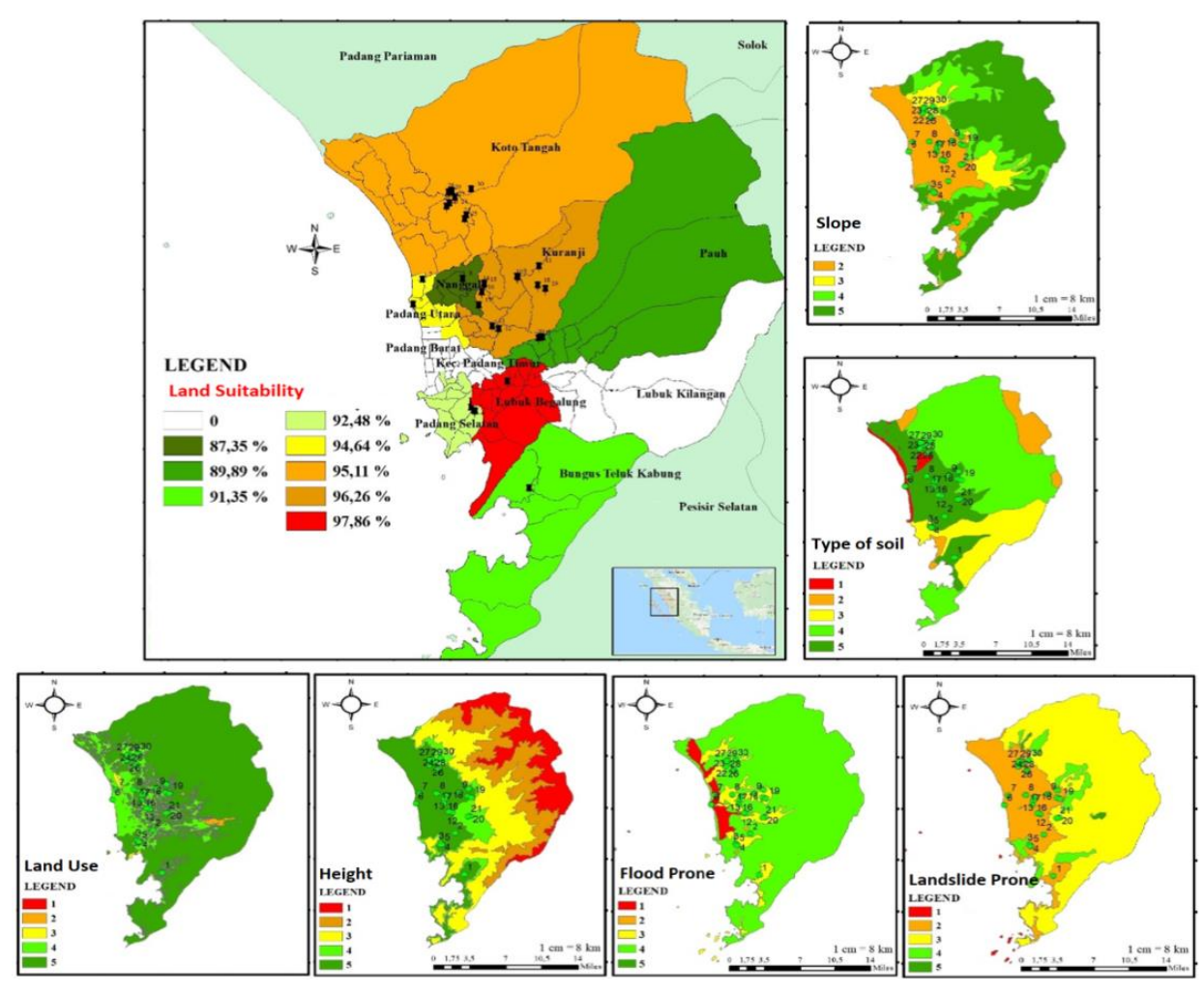

Fig 2. Map of Pond Land Suitability for Catfish Cultivation in Padang City

Published By:

Blue Eyes Intelligence Engineering

\& Sciences Publication

72 (C) Copyright: All rights reserved.

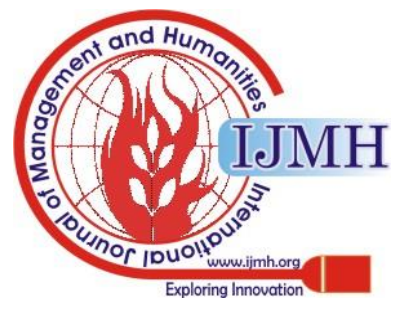


The next pond land suitability parameters are the distance of research location from transportation and water source (rivers/drainage). The average distance of research location from means of transport or highway is not too far, the closest distance is at the point of the 23 cultivation location in Koto Tangah sub-district with a distance of $88.97 \mathrm{~m}$, and the farthest distance is at the 7 cultivation point in North Padang sub-district with a distance of $105.82 \mathrm{~m}$. The average distance of research site from the water source is also not too far, the closest distance is at point of cultivation location to 4 in South Padang sub-district with distance $97.49 \mathrm{~m}$, and the farthest distance is at the point of cultivation location to 3 in South Padang sub-district with a distance of $103.64 \mathrm{~m}$.

The next parameters are slope, type of soil, land use, height, flood-prone and landslide-prone [Fig 2]. Map obtained from the Public Works Department and Padang city Spatial planning. Each Parameter of pond land suitability is divided into classes. After the overlay on all the parameters, then the result of one map of pond land suitability for catfish cultivation in Padang City can be seen in Fig 2. In Fig 2 is rated 15 (low)-25 (high) with a colour indicator (low)-red (high), value 15 still belongs to the category of pond land suitability for the cultivation of catfish, but the value 15 is the low result of the calculation of cultivation land Obtained from every point of cultivation location. Therefore, the number of 25 locations is increasingly suitable to serve as a cultivation area. The more the red colour will indicate the more suitability the region be the location of the catfish cultivation and the bluer, signifying the lower level accordingly to the region to be the location of the catfish cultivation. The research location has largely been in the red-coloured area. This indicates that the catfish cultivation in Padang City have put their pond or fish cultivation location in a region suitable because it meets the criteria of the parameters that have been tested.

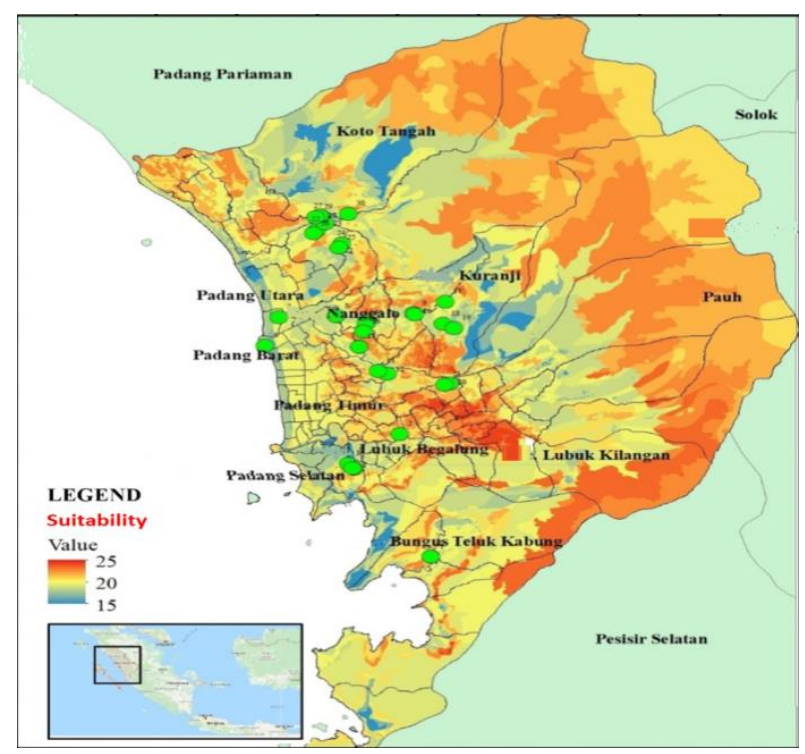

Fig 3. Map of Locations Suitability Value for Catfish Cultivation in Padang City

From Fig 3 It appears that the location that has a value closer to No. 25 is dominated by Kuranji sub-district. This is because the Kuranji sub-district is intended for cultivation area (paddy, fields, gardens, ponds). The catfish cultivation in Kuranji sub-district also get a high value of $96.26 \%$, the cultivation in Padang City. safe from flood and landslide. too far from an average of 94.5 meters, the distance of research location from the water source is also not too far Averaging 497.50 meters. Kuranji sub-district also supported by soil type in the dominant Kuranji sub-district is alluvial land, a pond land that is suitable for cultivation, slope and altitude in sub-district Kuranji also not too steep, as well as Kuranji sub-district is also safe from flood-prone and landslide-prone. Furthermore, to know from the 6 map parameters (slope, type of soil, land use, height, flood-prone and landslide-prone) are most statistically influential of each individual in the formation of pond land suitability map catfish cultivation in Padang city then needs to do T-test.

The result of the influence of each parameter to the pond land suitability of catfish cultivation in Padang City can be seen $n$ in Table 4 is seen that the highest value of the calculated T-test in land use parameters is with a value of 267.081. The value indicates that the use of land parameters most influence the pond land suitability of catfish cultivation parameter with a value of 54.957. The value signifies that the lower altitude parameter affects the pond land suitability of

Table-4 T-test Result of Pond Land Suitability of Catfish Cultivation in Padang City

\begin{tabular}{lccccc}
\hline \multirow{2}{*}{ Model } & \multicolumn{2}{c}{$\begin{array}{c}\text { Unstandardized } \\
\text { Coefficients }\end{array}$} & $\begin{array}{c}\text { Standardized } \\
\text { Coefficients }\end{array}$ & \multirow{2}{*}{$T$} & Sig. \\
\cline { 2 - 4 } & B & $\begin{array}{c}\text { Std. } \\
\text { Error }\end{array}$ & Beta & & \\
\hline (Constant) & 9,945 &, 042 & & 236,909 &, 000 \\
Flood &, 421 &, 005 &, 169 & 92,870 &, 000 \\
Height &, 310 &, 006 &, 108 & 54,957 &, 000 \\
Soil type &, 618 &, 004 &, 282 & 146,448 &, 000 \\
Landslide &, 261 &, 004 &, 124 & 58,374 &, 000 \\
Land use &, 661 &, 002 &, 463 & 267,081 &, 000 \\
Slope &, 807 &, 005 &, 294 & 169,322 &, 000 \\
\hline
\end{tabular}

From all parameter maps, it can be seen that the most land use maps are classified in class 5, i.e the high class or class that is included in the category very suitable for catfish

\section{CONCLUSION}

Analysis of pond land suitability using 9 parameters and T-test, obtained the results of the area that is very suitable for catfish cultivation in Padang City is Kuranji sub-district with the biggest parameter affecting is the land use parameter. The pond land suitability in Kuranji sub-district also received a high score of $96.26 \%$, the distance of the research location and transportation facilities was not too far which was an average of 94.5 meters, the distance of the research location from the water source was also not too far ie an average of 497, 50 meters. Kuranji sub-district is also supported by the Alluvial soil type that is suitable for cultivation, slope and height in Kuranji sub-district is also not too steep, and also

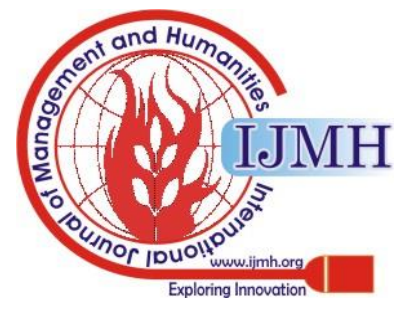




\section{ACKNOWLEDGEMENT}

I as the writer say thanks to the Chairman of the Postgraduate of Bung Hatta University, Chairman of the GIS/Mapping Laboratory of Universiti Kebangsaan Malaysia, Government of Padang City (Service of Marine and Fisheries) and fellow students involved in the research.

\section{REFERENCES}

1. Badan Pusat Statistik (BPS) Kota Padang. PDRB Kota Padang Atas Dasar Harga Berlaku menurut Lapangan Usaha 2017. Government of Padang City, 2018

2. H.S. Azrita and H. Syandri, Morphological character among five strains of giant gourami, Oshpronemus gouramy Lacepede, 1801 (Actinopterygii: Perciformes: Osphronemidae) using a truss morphometric system. International Journal of Fisheries and Aquatic Studies, Vol. 2, Issue. 6, pp. 344-350, 2015

3. Dinas Kelautan dan Perikanan Kota Padang. 2016. Produksi Perikanan Budidaya Dinas Kelautan dan Perikanan Kota Padang pada tahun 2013-2015

4. K. Hua, J.M. Cobcroft, A. Cole, K. Condon, D.R. Jerry, A. Mangott, J.M. Strugnell, The Future of Aquatic Protein: Implications for Protein Sources in Aquaculture Diets. One Earth, Vol. 1, Issue. 3, pp.316-329, 2019

5. A. Munzir, The Sustainability of Catfish Aquaculture in Coastal Suburb of Padang, Indonesia. International Journal of Real Estate Studies. Vol 11, Issue. 1, 2017

6. S. Aisyah and A. Munzir, Studi Pendahuluan Analisis Sistem Produksi Pembesaran Ikan Lele (Clarias batrachus) di Kota Padang Sumatera Barat. Prosiding Simposium Nasional Magister (SINMAG), Vol. 1, Issue. 1, 2017

7. Badan Pusat Statistik (BPS) Provinsi Sumatera Barat. Produksi Budidaya Perikanan Darat Menggunakan Media Kolam di Kabupaten/Kota Sumatera Barat 2016. Government of West Sumatra Province, 2017

8. A. Putra, Evaluasi Kesesuaian Pemanfaatan Ruang Pada Kawasan Pesisir Teluk Bungus Kota Padang [Tesis]. Pascasarjana Universitas Andalas, 2017

9. D. Prayoga, 2011. Evaluasi Kesesuaian Lahan Budidaya Tanaman dengan Menggunakan Logika Fuzzy [Skripsi]. Fakultas Matematika dan Ilmu Pengetahuan Alam. Institut Pertanian Bogor, 2011

10. R. Zamroh, Analisis Perubahan Penggunaan Lahan Untuk Permukiman Di Kecamatan Kaliwungu Dengan Sistem Informasi Geografis. Jurnal Ilmiah Pendidikan Geografi. Vol. 2, Issue. 1, 2014

11. Arliyus, U. Bulanin and L. Mayasari, Kesesuaian Lahan Wisata Pantai di Pulau Angso Duo Kota Pariaman Sumatera Barat. Prosiding Seminar Nasional Kelautan dan Perikanan III 2017 Universitas Trunojoyo Madura, 2017

12. P. Kurniawan, H. Syandri dan Arliyus, Analisis Kesesuaian Lokasi Suaka Perikanan Nago Sakti Di Nagari Pangkalan Kecamatan Pangkalan Kabupaten Lima Puluh Kota. Jurnal Program Pascasarjana Universitas Bung Hatta. Vol 11, No 1, 2017

13. SNI 01-6484.5-2002. Standar Nasional Indonesia Budidaya Ikan Lele Dumbo (Clarias gariepunus) Kelas Pembesaran pada Kolam.

14. F. Yulianda, Ekowisata Bahari Sebagai Alternatif Pemanfaatan Sumberdaya Pesisir Berbasis Konservasi. Seminar Sain pada Departemen Manajemen Sumberdaya Perairan. Fakultas Perikanan dan Ilmu Kelautan. Institut Pertnian Bogor, 2007

\section{AUTHORS PROFILE}

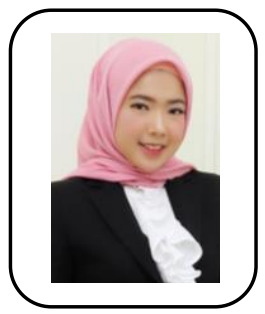

Siti Aisyahis, is a research and lecturer in Study Program of Business Fishing, Polytechnic of Pariaman Marine and Fisheries - Indonesia, obtained the Master degree in Bung Hatta University - Indonesia. She is actively involved in any researches regarded to fishing cultivation, coastal management and produces several scientific works in the form of journals. She is the winner ambassadors of the action to popularize eating fish (GEMARIKAN) in West Sumatra Province 2019 and the best graduate bachelor of fisheries and Masters Program of Aquatic, Coastal and Marine Resources (SP2K) Bung Hatta University 2019.

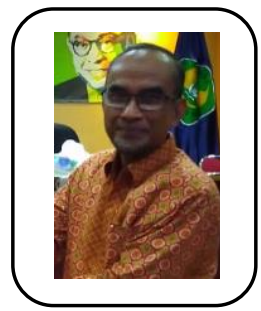

Abdullah Munzir, is a associate professor of socio-economic and management of aquatic resources in Bung Hatta University, obtained the Ph.D degree in Doctor Program of Rural Development Theory and Policy - Universität Hohenheim - Germany, 2001. He is actively involved in any researches regarded to socio-economic fisheries, aquaculture and produces several scientific works in the form of SINTA-Indonesia indexed journals (ID: 5997027). He is Chairman of LPPM Bung Hatta University and former expert, Coordinator of the Regional Economic Development Program of West Kalimantan Province, Cooperation of BAPPENAS and GIZ Germany 2009-2012.

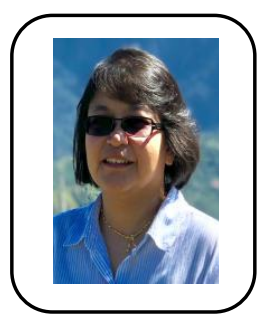

Muzzneena Ahmad Mustapha, is a professor of management of coastal and marine areas, Fakulti Sains \& Teknologi, Universiti Kebangsaan Malaysia, obtained the Ph.D degree in Graduate Schools of Hokkaido University - Japan. She is actively involved in any researches regarded to oceanography, coastal management and produces several scientific works in the form of Scopus indexed journals (ID: 23100915000) and scientific books both national and international publications. She is Chairman of Graduate Schools, Earth Science and Surrounding Nature - Universiti Kebangsaan Malaysia.

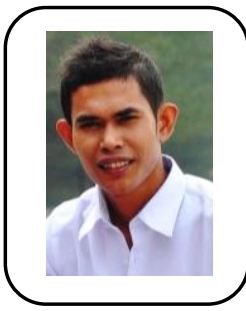

Aprizon Putra, is a research and lecture assistant of environmental sciences, Padang State University, obtained the Master degree in Environmental Science at Andalas University Indonesia, 2017. He is actively involved in any researches regarded to coastal and small islands management, natural disaster, geography physical and produces several scientific works in the form of Scopus indexed journals (ID: 57192951135). He is a winner of the Adi Bakti Mina Bahari national award in marine research 2014 .

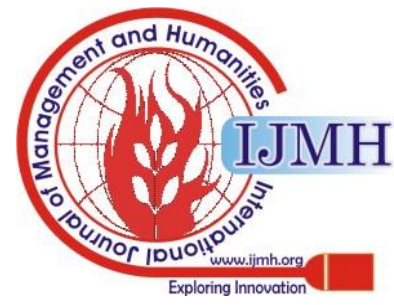

